\title{
THE EFFECT OF POSTURE ON THE MECHANICS OF BREATHING DURING INTERMITTENT POSITIVE PRESSURE: RESPIRATION*
}

\author{
H $\mathbb{B}$ Fatrley, M B, B S, F F A R $S, \nmid$ ANd Douglas D Hunter, M D
}

ChANGIES IN POSTURE durmg anaesthesia are a well-recognized cause of ventilatory embarrassment to the patient ${ }^{1,2}$ Several authors have reported variations in vital capacity when conscious subjects have been placed in different surgical positoons ${ }^{34,5}$ These variations bear a very indurect relationshup to changes occurring in anaesthetized patients who are not breathing maximally ${ }^{1}$ Simularly, the measurement of changes in tidal volume resulting from changes in position ${ }^{2}$ indicate a change in work-load only very indirectly This study was designed to investigate the magnitude of the changes in the work of breathing required to maintain satusfactory ventilation in the anaesthetized subject when he is pos1toned for surgery, using the pressure-volume loop as a basis for measurement

\section{METHOD}

Thirty adult patients, clinically normal from the cardiopulmonary standpoint, were divided into three groups of ten The mechanics of respiration were measured in each group, in three different positions

Group I Supine, sitting, and right lateral positions

Group II Supine, lithotomy, and $45^{\circ}$ Trendelenburg positions

Group III Prone on a Mackay frame ${ }^{\ell}$ well Alexed, prone on a Mackay frame flattened but with abdomen clear of the table, and supine

\section{Anaesthesia}

All patuents were premedicated with pantopon and hyoscine, anaesthesia was induced with sodium thiopentone and maintained with nitrous oxide oxygen in a proportion of 21 Sufficient $d$-tubocurarine was given to plevent spontaneous respiratory efforts, while ventilation was mantaned at a tidal volume of $600 \mathrm{~mL}$, twenty tumes per minute A $95 \mathrm{~mm}$ endotracheal tube was used in all except three patients in whom only a $9 \mathrm{~mm}$ tube could be passed A Morch piston respurator ${ }^{7}$ with the aur intake converted to accept anaesthetic gases from a reservour bag, and a Morch non-return valve, were employed in all cases

\section{Instrumentation}

Pressure gradients across the lung-thoras were detected by a Statham PR23 differentual transducer, one side of which was connected to a point immediately proxumal to the endotracheal tube. This transducer was calibrated by a water

- From the Anaesthesia Research Laboratory of the University of Toronto

PIn recent of Medical Research Councl Grant MBA-1213.

$\$$ Medical Research Councul Graduate Student 
manometer before each measurement Transpulmonary pressure gradients were obtained by connecting the other side of the transducer to a $15 \mathrm{~cm}$ oesophageal balloon, inserted in the lower third of the oesophagus The pressure-volume characteristics of this balloon were such that no pressure changes were registered when it was filled with $\mathrm{O}-4 \mathrm{~mL}$ of aur Maximum respiratory pressure fluctuations were obtained by insertung the balloon, open to atmospheric pressure, prior to connecting it to the transducer Aspiration subsequently showed that negative intrathoracic pressure had draw in 1-1 $5 \mathrm{~mL}$ of aur Aur flow was detected by a No 2 Fleisch pneumotachograph, placed between the non-return valve and the endotracheal tube The screen was heated by a 5 volt current The pneumotachograph was calibrated with a contnuous flow of aur using FisherPorter flow meters, accunate to $\pm 1 \%$ Flows of an were converted to values for $21 \mathrm{~N}_{2} \mathrm{O} \mathrm{O}_{2}$ mixtures on the basis of the dufference in physical charactenstics Thus $100 \mathrm{~L} / \mathrm{min}$ of arr $=8489 \mathrm{~L} / \mathrm{mm} \mathrm{N}_{2} \mathrm{O} \mathrm{O}_{2}$, at $147 \mathrm{P} \mathrm{S}$ I A and $70^{\circ} \mathrm{F}$ The pressure differential across the pneumotachograph screen was detected by a Statham PM5 transducer Volumes were derived by electrical integration of flow, using a Grass U1-1 integiator

Pressure differential, anr flow, and volume were recorded contnuously on a Grass Polygraph Pressure and volume changeses were displayed on a| Tektronix dual beam osclloscope, connected to the output of the Grass driver amplifiers and calibrated at the same time as the latter A simple switching device permitted the output from the flow channel to be substatuted for volume on the $Y$ axis Thus, either pressure-volume or pressure-flow loops could be displayed Photographs of loops were made on Polarold film for measurement purposes, the difference in screen and film calıbration was constant, for a given camera lens and screen-tofilm distance, and the appropriate conversion factor was applied to all photographic measurements

\section{Procedure}

Each patrent was measured only when the records of pressure, flow, and volume were steady In each position, a pressure-volume loop was photographed, switching was performed on the next respiratory cycle and the film was then reexposed, this time to the pressure-flow loop of the third cycle Thus the pressurevolume and pressure-flow loops of two simular cycles were superimposed on the same film The cycles from which the loops were recorded were marked automatacally on the polygraph paper, by a switch syachronized with the shutter release cable This provided the opportumity for subsequent checking of loop measurements from the polygraph trace and confirmation that the two loops were from comparable cycles In each position, loops obtamed for lung-thorax and then for lung mechanics

During intermittent positive pressure, lung complance falls, and this may be increased by a single, large inflation ${ }^{8}$ Simularly, aurway resistance may be reduced by a series of large breaths ${ }^{9}$ In the present series, every effort was made to carry out measurements durng stable ventulatory circumstances and to avold such large inflanons Once recordings were stitrted, all measurements were made within as short a time interval as possible 


\section{Measurements}

Each loop was traced on millımeter squared graph paper The dynamic complance line was drawn between points of minimum and maximum volume Where the shape of the loop was such that there was a pressure change with no volume change at end-inpiration or at end-expuration, the exact points of zero flow were determined by reference to the Grass recording and to the superimposed pressure-flow loop, as described by Watson ${ }^{10}$ (see Discussion) Elastic work

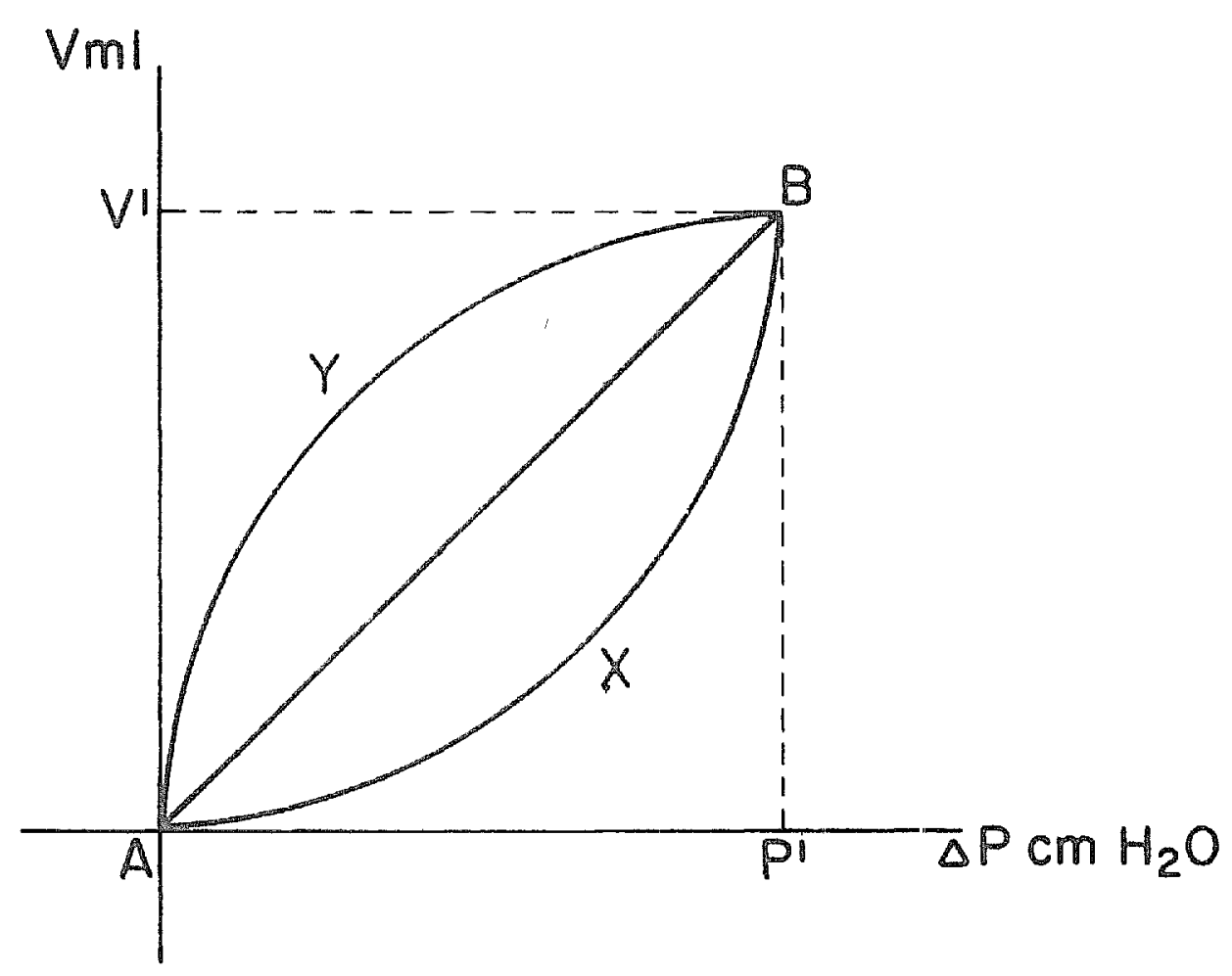

Figure 1 Idealized pressure-volume loop $A K B Y A B$ represents the dynamic complance line

was calculated by measurning the area of the triangle $A B V^{\prime}$ (see $F_{1}$ 1) Nonelastic work was measured from the area of the half loop $A B X$ When any part of the expiratory half of the loop crossed the $Y$ axas this area was added to the non-elastic work This occurred in a few instances in the prone position. In keeping with the standard form for spontaneous respuation, all work values were multplied by the respiratory rate and quoted in $\mathrm{kg} \mathrm{M} / \mathrm{min}$ Dynamic compliance was obtaned by dividing the volume $V^{\prime}$ by the pressure differential $\mathbb{P}^{\prime}$

\section{Results}

The anthmetic means of the results obtanned are shown in Tables I, II, and III Other authors ${ }^{11,12}$ have shown the lack of validity of oesophageal balloon values obtained in the supme position Consequently, only the results obtamed in the situng, nght lateral, and prone positions have been used in calculations separating lung and thoracic wall components from total lung-thorax values

\section{Statustrcal Analysis}

Since the resistances to lung and chest wall expansion vary markedly with body size, ${ }^{13}$ each group of ten values showed a large varnation from the mean. While 
TABLE I

LUng-Thorax MLEAsurements

(Each figure represents the anthmetic mean of values for ten patients)

\begin{tabular}{|c|c|c|c|c|c|}
\hline Group & Positions & $\begin{array}{l}\text { Total work, } \\
\mathrm{kg} \mathrm{M} / \mathrm{mm}\end{array}$ & $\begin{array}{l}\text { Non-elastic } \\
\text { work, } \\
\mathrm{kg} \mathrm{M} / \mathrm{mmn}\end{array}$ & $\begin{array}{l}\text { Elastic work, } \\
\mathrm{kg} \mathrm{M} / \mathrm{mun}\end{array}$ & $\begin{array}{l}\text { Dynamic } \\
\text { compliance, } \\
\mathrm{L} / \mathrm{cm} \mathrm{H}_{2} \mathrm{O}\end{array}$ \\
\hline (10 patuents) & $\begin{array}{l}\text { Supine } \\
\text { Sitting } \\
\text { Right lateral }\end{array}$ & $\begin{array}{l}097 \\
092 \\
091\end{array}$ & $\begin{array}{l}046 \\
038 \\
041\end{array}$ & $\begin{array}{l}051 \\
053 \\
050\end{array}$ & $\begin{array}{l}0077 \\
0073 \\
0076\end{array}$ \\
\hline$\underset{\text { (10 patients) }}{\text { II }}$ & $\begin{array}{l}\text { Supine } \\
\text { Lithotomy } \\
45^{\circ} \text { Trendelenburg }\end{array}$ & $\begin{array}{l}092 \\
096 \\
10\end{array}$ & $\begin{array}{l}044 \\
047 \\
049\end{array}$ & $\begin{array}{l}047 \\
049 \\
052\end{array}$ & 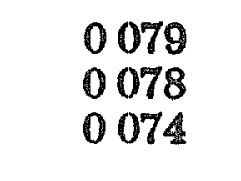 \\
\hline $\begin{array}{c}\text { III } \\
\text { (10 patients) }\end{array}$ & $\begin{array}{l}\text { Prone flexed } \\
\text { Prone flat } \\
\text { Supine }\end{array}$ & $\begin{array}{l}099 \\
093 \\
082\end{array}$ & $\begin{array}{l}039 \\
039 \\
043\end{array}$ & $\begin{array}{l}059 \\
054 \\
039\end{array}$ & $\begin{array}{l}0086 \\
0071 \\
0089\end{array}$ \\
\hline
\end{tabular}

Significant dufferences

Group I Non-elastic work $\mathbb{R}$ lateral < supune > sithng

Group II Elastic work

$\left.\begin{array}{l}\text { Non-elashic work } \\ \text { Total work }\end{array}\right\}$ Trendelemburg $\mid>$ supine

Dynamic compliance Trendelenburg $<$ supine

Group III Elastic work Prone flexed $>$ prone llat $>$ supine

Total work Prone flexed $>$ supine $<$ prone flat

Dynamic compliance Prone flexed $<$ supine $>$ prone flat

TABLE II

LUNG MEASUREMENTS

(Each figure represents the anthmetic mean of values for ten patients)

\begin{tabular}{|c|c|c|c|c|c|}
\hline Group & Positions & $\begin{array}{l}\text { Total work, } \\
\mathrm{kg} \mathrm{M} / \mathrm{mun}\end{array}$ & $\begin{array}{l}\text { Non-elastic } \\
\text { work, } \\
\mathrm{kg} \mathrm{M/min}\end{array}$ & $\begin{array}{l}\text { Elastic work, } \\
\mathrm{kg} \mathrm{M} / \mathrm{min}\end{array}$ & $\begin{array}{l}\text { Dynamic } \\
\text { compliance, } \\
\mathrm{L} / \mathrm{cm} \mathrm{H}_{2} \mathrm{O}\end{array}$ \\
\hline $\begin{array}{c}\mathbb{I} \\
\text { (10 patients) }\end{array}$ & $\begin{array}{l}\text { Sitting } \\
\text { Right lateral }\end{array}$ & $\begin{array}{l}068 \\
063\end{array}$ & $\begin{array}{l}033 \\
035\end{array}$ & $\begin{array}{l}032 \\
028\end{array}$ & $\begin{array}{l}0126 \\
0150\end{array}$ \\
\hline $\begin{array}{c}\text { III } \\
\text { (10 patents) }\end{array}$ & $\begin{array}{l}\text { Prone flexed } \\
\text { Prone flat }\end{array}$ & $\begin{array}{l}0.52 \\
059\end{array}$ & $\begin{array}{l}031 \\
036\end{array}$ & $\begin{array}{l}020 \\
023\end{array}$ & $\begin{array}{l}0199 \\
0175\end{array}$ \\
\hline
\end{tabular}

No significant differences

TABLIT III

Thoracic Walt Mrasurements

(Each figure represents the arthmetic mean of values for ten pathents)

\begin{tabular}{clcccc}
\hline \hline Group & Positions & $\begin{array}{c}\text { Total work, } \\
\mathrm{kg} \mathrm{M} / \mathrm{min}\end{array}$ & $\begin{array}{c}\text { Non-elastic } \\
\text { work, } \\
\mathrm{kg} \mathrm{M} / \mathrm{mun}\end{array}$ & $\begin{array}{c}\text { Elastac work, } \\
\mathrm{kg} \mathrm{M} / \mathrm{min}\end{array}$ & $\begin{array}{c}\text { Dynamic } \\
\text { complance, } \\
\mathrm{L} / \mathrm{cm} \mathrm{H}_{3} \mathrm{O}\end{array}$ \\
\hline I & Sitting & 026 & 006 & 021 & 0213 \\
(10 patients) & Rught lateral & 029 & 006 & 022 & 0210 \\
III & Prone flexed & 047 & 008 & 039 & 0189 \\
(10 patents) & Prone flat & 036 & 005 & 031 & 0171 \\
\hline
\end{tabular}

Signnicant dufferences, Group III, elastic work Prone flexed $>$ prone flat 


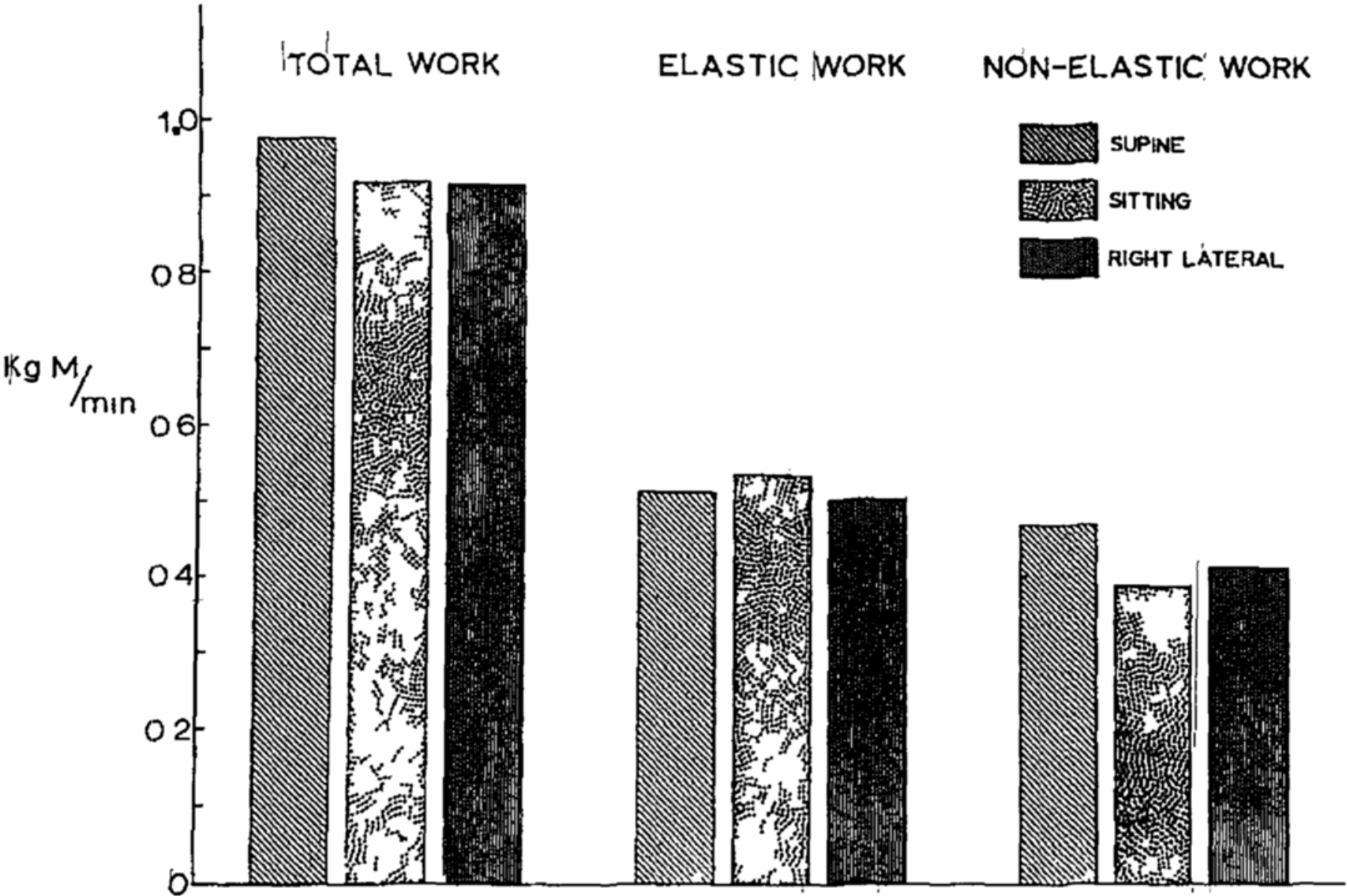

Figure 2 Comparison of anthmetc means of total elastic and non elastic work in supine, sitting and nght lateral positions

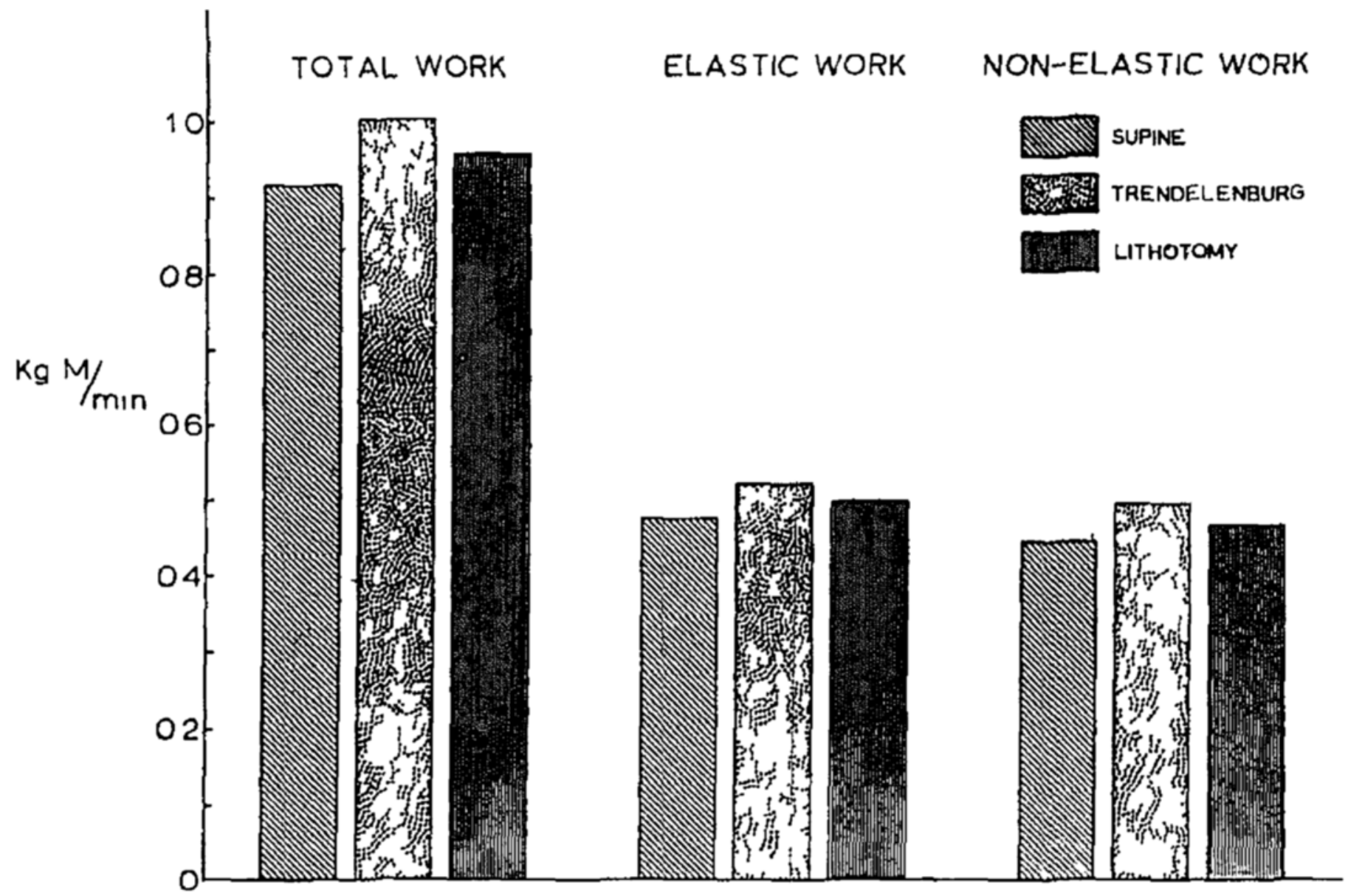

Ficune 3 Companison of anthmetc means of total, elastic and non elastac work in supine lithotomy and 45 Trendelenburg positions 


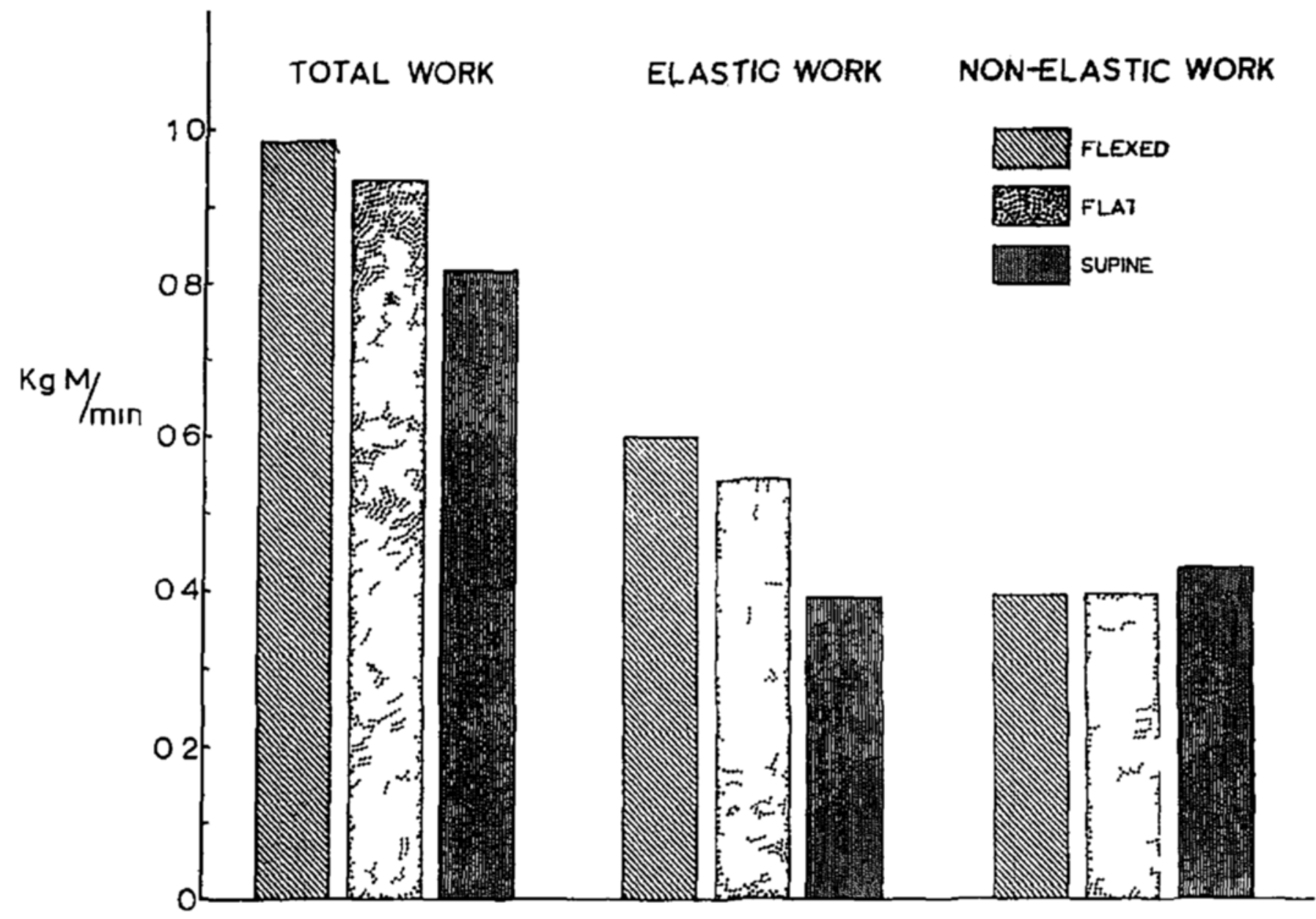

Figure 4 Companson of anthmetic means of total elastic and non-elastac work in prone flexed prone flat, and supine positions

this could have been reduced by relating each value to body weight this was considered less useful than lettng each patient serve as his own control

Lung thorax values (Table I Figs 23 and 4) The total raw data were submitted to an analysis of vanance from which it was found that the following means were signuficantly different at the 5 per cent level

Group I Non elastic work was greater in the supine position than in either the sitting or right lateral positions

Group II Elastic non elastic and total work were greater and the dynamic compliance lower in the Trendelenburg than in the supine position

Group III Elastic and total work were greater in both prone positions than in the supine position Elastic work was greater when the Mackay frame was flexed than when flat Dynamic compliance was lower in both prone posi tons than in the supine position

Lung values (Table II) The total raw data were submitted to an analysis of vanance and none of the means were found to be significantly different

Thoracic wall values (Table III) Standard deviations and the standard error of the means were calculated for the differences between values for each parr of positions These figures were submitted to a $t$ test and only one pair of values were found to be significantly different at the 5 per cent level Thus the thoracic wall elastc work was greater when the Mackay frame was flexed than when it was flattened 


\section{Discussion}

During spontaneous respiration, in conscious subjects, ventilation is adjusted to maintain the arterial carbon dioxade tension within very narrow limits Tidal volumes and respiratory rate combine to strike a compromise between the need to overcome dead space-largely a matter of elastic work-and variations in nonelastic resistance, overcome by changes in resprratory frequency ${ }^{14}$ Consequently, values for work are quoted per minute in order to eacompass both factors.

During intermittent positive pressure respiration, the size of the thdal volume is determined by the respirator When the latter is patient-triggered, the patient may determine his own respiratory frequency but, during controlled respiration, this too is determined mechanically Thus, values for work obtaned under these curcumstances bear little comparison with those quoted for spontaneous respiration In this study, most patients were hyperventilated ( $12 \mathrm{~L} / \mathrm{mm}$ ), even allowing for mechanical dead space This accounts in part for the relatively high work values

During spontaneous respiration, the shape of the pressure-volume loop is determined by the characteristics of the lungs and airway To some extent, the shape of one patient's loop is comparable with that of another However, when the respiratory pattern is determined by a mechanical ventilator, the shape of the loop also depends on the characteristics of the respirator-particularly with regard to its inspiratory air flow pattern Expiration will usually be passive, unless the respirator assists in this phase, but may be modufied slightly by the

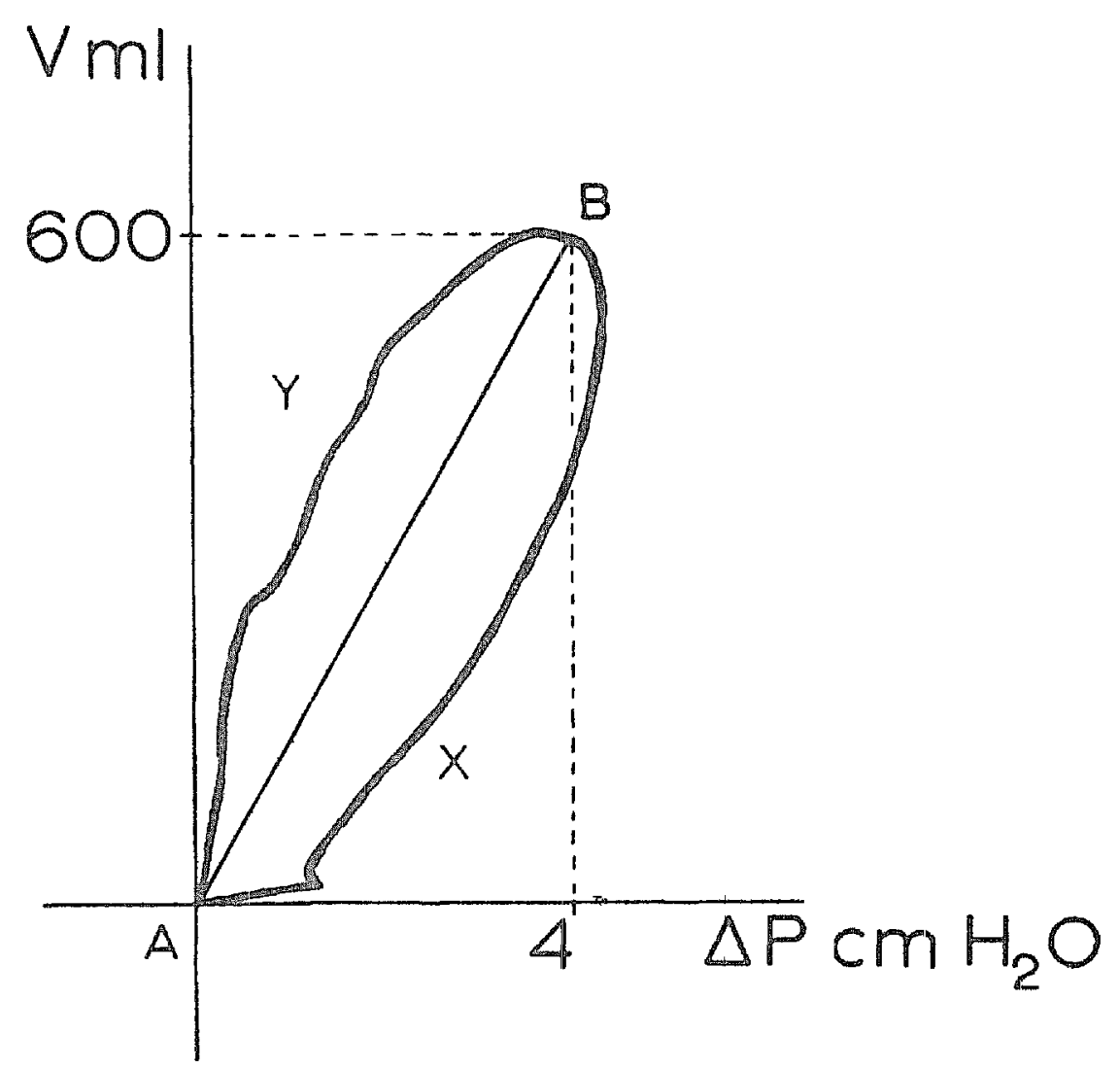

Figure 5 Typical pressure-volume loo obtained wath Morch piston respirator (The honzontal portion at the start of inspiration is related to the transient "surge" of air when the Morch valve opens ) 
expiratory valve resistance Both inspiratciry and expiratory non-elastic resistance will be contributed to by endotracheal intubation Thus, loops obtained from patients on respirators will only be comparable when identical respirator circumstances have been employed and when ventilation has been delivered through aurways of identical resistance These requirements were met, in this series, by ventilating all patients identically and letting each patient serve as his own control

Watson has described the relatively square loop produced by the Radcliffe respirator ${ }^{10}$ and his method of determining the points of no flow has been used in this series The Morch respirator produces a more sinusordal air flow pattern and consequently a more "classical" pressure-volume loop, as shown in Figure 5

Changes in body position can be expected to influence the mechanics of respiration in a variety of ways, such as by alterations in lung volume (particularly FRC), , ,15,16 changes in intrapulmonary blood volume, and interference with thoracic wall movements and with diaphragmatic descent Unfortunately, the measurement technique used can only separate the lung contribution in certain positions and, in these, any changes produced were too small to be statistically significant However, the nature of changes in work-load can be detected in many instances Thus, in the prone position on bolsters, the additional load is primanily elastic resistance to chest wall expansion, whereas, in the Trendelenburg position, both elastic and non-elastic work are increased

The magnitude of changes in work of breathing necessary to maintain constant ventilation, despite changes in body position, can be calculated from Tables I-III For example, the largest percentage change produced was in moving from the prone flexed to the supine position, when the total lung-thorax elastic work fell by 34 per cent, although the total work changed by only 17 per cent Tiltung patients from supine to $245^{\circ}$ Trendelenburg position only umposed an additional 9 per cent on the total lung-thorax work (Table I)

Presumably, these percentage changes would be greater with pathological states, such as obesity, ascites, hydrothoras, pneumothorax, pneumonia, pulmonary congestion

In a study on a sernes of supine paralysed patients, Watson was unable to demonstrate any thoracic wall non-elastic resistance ${ }^{10}$ Durng intermittent pos1tave pressure in the paralysed patient, the proportion of the chest wall contribution to total resistance probably depends on the size of the tidal volume and the extent to which this passes the neutial chest wall position In this series, chest wall non-elastic resistance accounted for 6 per cent of the total work in the sittung position, 7 per cent in the right lateral, 8 per cent in the prone flexed, and 3 per cent in the flat prone position

One unexpected finding was the unusually low elastic work in patients turned from the prone to the supine position The reason for this is not apparent, from the avallable data, but it may be related to the relatively high inflation pressures necessary in the prone position, a resulting low intrapulmonary blood volume and an improved aur distribution might account for the subsequent low elastic work when patients were turned to the supine position

The reason that the lung-thorax non-elastic resistance is higher in the supme 
than in the sitting and nght lateral positions is not apparent Again, lung and chest wall components cannot be separated, but probably the "falling away" of the abdominal contents, in the last two positions, plays a significant role Changes in lung volume may be an important factor

From the practical standpoint, one must conclude that certain changes in pos1tuon do influence the respuratory work load significantly 1 in the paralysed anaesthetrzed patient Under such circumstances inflation pressure must be adjusted appropriately, if constant ventilation is to be maintaned

\section{SUMMary}

Mechanics of breathing have been measured in thirty curanzed anaesthetized normal adults, ventilated by intermittent positive pressure The magnitude and nature of the changes in work of breathing requn ed to maintain constant ventilation despite changes in body position have been assessed Possible reasons for these changes are suggested

\section{Résumé}

Chez 30 malades adultes sous anesthésie, nous avons mesuré les composantes mécanıques de la respuration en employant les courbes pression-volume obtenues au cours de la respiration avec pression positive intermittente Nous avons mesuré le travall total de la respiration, le travall élastıque, le travall non élastique et la compliance dynamique pour l'ensemble poumon-thorax et, cela, dans les positions sulvantes assise, latérale droite, lithotomie, Trendelenburg $45^{\circ}$ et ventrale $\mathrm{La}$ part du poumon et de la paroi thoracique dans ces données est notée pour les positions assise, latérale droıte et ventrale Une analyse statıstıque des résultats obtenus a été farte et nous avons souligné l'mportance des différences appréc1ables du travall-poids respiratoire

\section{REFERENCES}

1 LITILe, D M, IR Posture and Anaesthesia Canad Anaesth Soc J 7 2 (1960)

2 JONIs, J $\mathbb{R}$ and JACOBY, J The Effect of Surgical Position on Respuration Surg Forum 5686 (1955)

3 CAST, E II and Stiurs, J A The Effect of Vanous Surgical Positions on the Vital Capacity Anesthesiology 729 (1946)

4 STtipien, $\mathbb{R}$ The Influence of Posture on Mechanics of Respiration and Vital Capacity Anesthesiology 9134 (1948)

5 Soralchur, $\mathbb{A}, \mathbb{E L}$ is, $\mathbb{D}$, Hrctox, $\mathbb{C}$, \& Grishimimer, $\mathbb{E}$ M Pulmonaty Function as Affected by Operatuve Position Anesthesiology 10577 (1949)

6 MAczay, I M A New Frame for the Positioning of Patients for Surgery of the Back Canad Anaesth Soc J 3279 (1956)

7 AvERx, E E, MORCF, E T, \& BENSON, D W Critzcally Crushed Chests J Thorac Surg 32291 (1958)

8 BENDIXEN, H H, HEDLEY-WhHYTC, J, \& LAVER, M B Increased Physiologic Shunting during Anaesthesia and Surgery Anesthesiology 24122 (1963)

9 BrIscoe, W A \& DuBors, A B Relatonship between Aurway Resistance, Aurway Conductance and Lung Volumes an Subjects of Different Age and Body Size $J$ Cin Investagation 371279 (1958)

10 WArson, W E Observations on the Mechancal Work of Intermittent Posituve Pressure Respiration Brit I Anaesth 34433 (1962) 
11 Mead, J \& Gaenszer, E A Esophageal and Pleural Pressures in Man, Upnght and Supine J. Appl. Physiol. 14. 81 (1959).

12 Ferris, B G, Jr, MEAd, J, \& Franx, $N$ Effect of Body Position on Esophageal Pressure and Measurement of Pulmonary Compliance J Appl Physiol 14521 (1959)

13 Coox, C D, Heli.jesen, P J, \& AGathow, S Relation between Mechanics of Respiration, Lung Size and Body Size from Burth|to Young Adulthood J Appl. Physiol 13. 349 (1958)

14 Otis, A B, FeNN, W O \& Rafn, $\mid H$ Mechanics of Breathing in Man J Appl Physiol $2592(1950)$

15 Marsinil, $R$ The Physical Properties of the Lungs in Relation to the Subdivisions of the Lung Volume Clin Sc1 16. 12 (1957)

16 Comroe, J H, Jr, Forster, R E, Dubors, A B, Briscoe, W A, and Carlsen, E The Lung 2nd ed Chicago Yearbook Medical Publishers (1962) 